\title{
Production of zinc enriched designer eggs through dietary supplementation
}

\author{
P.S. Megha' ${ }^{1}$, V. Ramnath ${ }^{2}$, K. Raji ${ }^{3}$, V. Babitha ${ }^{4}$ and Binoj Chacko ${ }^{5}$ \\ Department of Veterinary Physiology, \\ College of Veterinary and Animal Sciences, Mannuthy, Thrissur, Kerala 680651 , \\ Kerala Veterinary and Animal Sciences University, Pookode, Wayanad, India.
}

\begin{abstract}
Citation: Megha, P. S., Ramnath, V., Raji, K., Babitha, V. and Binoj Chacko. 2021. Production of zinc enriched designer eggs through dietary supplementation. J. Vet. Anim. Sci. 52(1): 77-80.
\end{abstract}

DOI: https://doi.org/10.51966/jvas.2021.52.1.77-80

Received : 30.11 .2020

Accepted: 18.12 .2020

Published: 01.01.2021

\begin{abstract}
Designer eggs have high market demand because of the consumers' willingness to purchase them owing to its' nutritional qualities additional to regular eggs. The current study was conducted to produce zinc enriched eggs by supplementing laying hens' diet with required levels of zinc as inorganic zinc sulphate $(75 \mathrm{mg} / \mathrm{kg}$ ). Thirty-two number of crossbred (White Leghorn $N$ strain and Desi) layer birds were given zinc enriched diet from 29 weeks of age for 12 weeks. The concentration of zinc in egg of birds supplemented with zinc diet was significantly higher $(p<0.01)$ than that of unsupplemented group. The egg zinc concentration of supplemented birds was elevated from $33.36 \pm 0.89 \mathrm{ppm}$ (control group) to $40.85 \pm 0.47 \mathrm{ppm}$ (supplemented group)
\end{abstract}

Keywords: Designer eggs, Zinc sulphate

Zinc is an essential trace micronutrient mineral which is an integral part of over 300 enzymes involved in carbohydrate, nucleic acid and protein metabolism. Zinc has a systemic role in fertility, antioxidation, skeletal and neurobehavioural functions. In addition, zinc plays a key role in the immune system, transport and the use of vitamin A. Many plant foods have high zinc content particularly cereal grains and legumes, but bioavailability is less due to presence of phytates. Though the richest zinc sources are animal products such as beef, pork and shellfish, they are expensive. Therefore, zinc deficiency is widely felt in human population. The zinc content of hen's eggs can be upgraded by relatively simple and economical dietary approaches and can be marketed at reasonable price.

${ }^{*}$ Forms part of the MVSc thesis submitted by the first author to the Kerala Veterinary and Animal Sciences University, Pookode, Wayanad, Kerala.

1. MVSc Scholar and corresponding author:email-meghaps7@gmail.com,Ph:8606597797

2. Professor and Head

3. Associate Professor

4. Assistant Professor

5. Assistant Professor and Head, University Poultry and Duck Farm

Copyright: (C) 2021 Megha et al. This is an open access article distributed under the terms of the Creative Commons Attribution 4.0 International License (http://creativecommons.org/licenses/by/4.0/), which permits unrestricted use, distribution, and reproduction in any medium, provided the original author and source are credited. 


\section{Materials and Methods}

\section{Experimental layout}

The study was conducted using thirty-two numbers of 28 weeks old crossbred (White Leghorn $\mathrm{N}$ strain $\mathrm{X}$ Desi) layer birds procured from All India Coordinated Research Projects (AICRP) on Poultry for Eggs, Mannuthy, KVASU. The birds were distributed in a completely randomized experimental design and they were placed into two treatment groups, each with four replicates having four birds in each replicate. All birds were fed with a standard layer diet and raised under standard managemental conditions up to 28 weeks of age at AICRP on Poultry for Eggs Mannuthy, KVASU. The birds were immunized against diseases as per standard protocol followed in the farm. On completion of 28 weeks of age, the birds were brought and housed in well ventilated cages of animal house attached to Department of Veterinary Physiology. They were kept at $24.5 \pm 0.5^{\circ} \mathrm{C}$ ambient temperature and at relative humidity ranging from $60-80$ per cent. A photoperiod of $16 \mathrm{~h}$ per day was ensured throughout the period.

\section{Feeding of birds with zinc enriched diet}

Zinc level in control diet was formulated according to BIS 2007 standards. Treatment group was provided with a diet incorporating inorganic zinc sulphate @ 75 mg/kg mash diet. The total ration was provided as a single lot in the morning. Water was provided ad libitum throughout the experimental period of 84 days.

\section{Estimation of zinc content of egg}

One egg was randomly selected from each treatment group at weekly interval and the contents of raw egg were subjected for microwave acid digestion to estimate $\mathrm{Zn}$ content. Three $\mathrm{mL}$ of pooled whole egg sample was subjected for digestion using $6.0 \mathrm{~mL}$ of $\mathrm{HNO}_{3}$ and $1.0 \mathrm{~mL}$ of $\mathrm{H}_{2} \mathrm{O}_{2}$ in teflon digestion vessel. The mixture was carefully stirred with a clean glass rod for 10 min before closing the vessel. Microwave digestion was set with the following program (Table 1).

The digested samples were analysed for $\mathrm{Zn}$ by Atomic Absorption Spectrometry standard method, (AOAC., 2016). The PinAAcle $900 \mathrm{H}$ Series AAS enabled a simple automated measurement of $\mathrm{Zn}$ using hollow cathode lamp of wavelength $213.86 \mathrm{~nm}$ and lamp current of $15 \mathrm{~mA}$. Calibration curve was plotted with standards ranging from 0 to $6 \mathrm{ppm}$ with a calibration equation non-linear through zero. Slit width of $0.7 \mathrm{~nm}$ ensured accurate analysis. The flame atomizer with a temperature of $2400^{\circ} \mathrm{C}$, was ideal for the measurement. Fuel and oxidant gases were acetylene $(2.5 \mathrm{~L} / \mathrm{min})$ and air $(10 \mathrm{~L} / \mathrm{min})$ respectively.

\section{Statistical analysis}

Results were expressed as means $( \pm$ SE). The statistical significance of difference or relation between the two treatments were analysed by CRD using the software Statistical Product and Services (SPSS) version 24.0 and the differences were considered statistically significant at $5 \%$ level $(p<0.05)$ (Snedecor and Cochran, 1994).

\section{Results and Discussion}

\section{Zinc content in egg sample}

Consumers are always driving the market for a new category of food with health benefits beyond the traditionally value. Zinc enriched eggs in the market have a potential demand because of its systemic role in immunocompetence, skeletal and neurobehavioural development.

Table 1: Microwave digestion programme

\begin{tabular}{|c|c|c|c|c|c|}
\hline Step & $\begin{array}{c}\text { Target temperature } \\
\left({ }^{\circ} \mathrm{C}\right)\end{array}$ & $\begin{array}{c}\text { Pressure (max) } \\
(\text { bar })\end{array}$ & Ramp time (min) & Hold time (min) & Power (\%) \\
\hline 1 & 165 & 30 & 5 & 10 & 50 \\
\hline 2 & 190 & 30 & 5 & 20 & 80 \\
\hline 3 & 50 & 30 & 1 & 10 & 0 \\
\hline
\end{tabular}


Table 2: Mean value of zinc concentration $(\mathrm{mg} / \mathrm{L}(\mathrm{ppm}))$ in eggs of different treatment groups

\begin{tabular}{|c|c|c|c|c|}
\hline \multirow{2}{*}{ Treatment group } & \multirow{2}{*}{ No of samples } & Mean value of amount (ppm) & \multirow{2}{*}{$p$-value } & \multirow{2}{*}{ F value } \\
\hline & & Mean \pm S.E. & & \\
\hline $\mathrm{T} 1$ & 12 & $33.36^{a} \pm 0.89$ & \multirow{2}{*}{$0.000^{* *}$} & \multirow{2}{*}{31.798} \\
\hline T2 & 12 & $40.85^{b} \pm 0.47$ & & \\
\hline
\end{tabular}

Means bearing same superscript within a column do not differ significantly $(p<0.05)$

** Highly significant $(p<0.01)$

Samples subjected for microwave digestion were analyzed for zinc by AAS and zinc concentration in egg yolk, when hens were supplemented with inorganic zinc sulphate at a level of $75 \mathrm{mg} / \mathrm{kg}$ mash diet are presented in the table 2

The effect of zinc feeding was highly significant $(p<0.01)$ for zinc concentration range in eggs. It was noticed that hens fed the diet enriched with inorganic zinc sulphate exhibited higher zinc level in eggs compared to other group under conventional feed. Supplemented zinc resulted in significant difference in zinc content of eggs. It was clearly noticed that egg zinc content increased significantly $(p<0.01)$ by increasing the zinc level to $75 \mathrm{mg} / \mathrm{Kg}$ diet.

In the present study, the mean zinc content in diet supplemented group (T2) was significantly $(p<0.01)$ greater than basal diet fed group ( $\mathrm{T} 1$ ) as represented in table 2 . These findings were completely agreed with the data of Kim and Patterson (2005) who confirmed that, linear increase in zinc supplementation through diet could result more pronounced incorporation of zinc in eggs. The present study findings are also supported by Stahl et al. (1988) who found an increase of 57-95\% zinc in eggs while feeding hens with elevated levels of zinc at the rate of $1861 \mathrm{mg} / \mathrm{kg}$ diet. This linear increment in zinc content of eggs through dietary supplementation could be attributed to the production of a trace mineral transporting protein called vitellogenin. Vitellogenin transport zinc from liver storage to ovaries (Richards, 1997).

Cousins (1985) reported that excess supplementation of zinc through diet would make the absorptive membrane more leaky, which allowed zinc to enter the cell and bind non-specifically to cell proteins and other ligands. Hence an optimum level of dietary supplementation $(75 \mathrm{mg} / \mathrm{kg}$ ) was selected for the present study, which had yielded $\mathrm{Zn}$ enriched eggs. As per BIS 2007, the recommended zinc requirement of layer birds (21-45 weeks) was $60 \mathrm{mg} / \mathrm{kg}$.

Reports of Williams et al. (1989), Plaimast et al. (2008), Bahakaim et al. (2014) and Aghaei et al. (2017) indicated a strong positive correlation between dietary as well as yolk content of zinc. The zinc content of enriched eggs obtained in the current study, $40.85 \pm 0.47 \mathrm{ppm}$ (T2) was comparable with the results Kaya et al. (2001) who reported a zinc level of 27.62 to $36.69 \mu \mathrm{g} / \mathrm{g}$ egg.

On contrary, when $80 \mathrm{mg} \mathrm{Zn}$ was introduced to the hens' basal diet, Skrivan et al. (2005) found no major variations in egg yolk, white and shell zinc content and they attributed the antagonistic effects of $\mathrm{Zn}$ and $\mathrm{Cu}$ as one of the reasons for non enrichment of eggs.

\section{Conclusion}

The dietary supplementation of hens with zinc is an effective approach to supply consumers with foods from animal sources that are enriched with zinc. Current findings showed that feeding of zinc supplemented diet to chickens offered a promising measure to enrich egg with zinc.

\section{Ethical approval and consent statement}

The experiment was approved by the Institutional Animal Ethics Committee (IAEC) of College of Veterinary and Animal Sciences, Mannuthy. 


\section{Acknowledgement}

The authors are thankful to the Kerala Veterinary and Animal Sciences University for providing the facilities needed for carrying out the research.

\section{References}

Aghai, A., Khosravinia, H., Mamuoei, M., Azarfar, A. and Shahriari, A. 2017. Effects of dietary supplementation of zinc and a-tocopheryl acetate on performance and zinc concentrations in egg and tissues of Japanese quails. Poult. Sci. J. 5: 57-64.

Bahakaim, A., Abdel Magied, H., Osman, S., Omar, A., Abdel Malak, N. Y. and Ramadan, N. 2014. Effect of using different levels and sources of zinc in

layer's diets on egg zinc enrichment. Egypt. Poult. Sci. J. 34: 39-56.

Cousins, R. J. 1985. Absorption, transport, and hepatic metabolism of copper and zinc: special reference to metallothionein and ceruloplasmin. Physiol. Rev. 65: 238309.

Kaya, S., Umucalilar, H. D., Haliloglu, S. and Ipek, H. 2001. Effect of dietary vitamin A and zinc on egg yield and some blood parameters of laying hens. Turk. J. Vet. Anim. Sci. 25: 763-769.

Kim, W. K. and Patterson, P. H. 2005. Effects of dietary zinc supplementation on hen performance, ammonia volatilization, and nitrogen retention in manure. $J$. Environ. Sci. Health B. 40: 675-686.

Plaimast, H., Sirichakwal, P., Puwastien, P. and Kijparkorn, S. 2008. Effect of supplementary zinc from organic and inorganic sources on laying performance and zinc deposition in eggs. Thai. J. Vet. Med. 38: 47-53.

Richards, M. P. 1997. Trace mineral metabolism in the avian embryo. Poult. Sci. 76: 152164.

Skrivan, M., Skrivanova, V. and Marounek, M. 2005. Effects of dietary zinc, iron, and copper in layer feed on distribution of these elements in eggs, liver, excreta, soil, and herbage. Poult. Sci. 84: 15701575.

Snedecor, G. W. and Cochran, W. G. 1994. Statistical Methods. (8 ${ }^{\text {th }}$ Ed.). Oxford and IBM Publishing Company, New Delhi, $313 p$.

Stahl, J. L., Cook, M. E. and Greger, J. L. 1988. Zinc, iron, and copper contents of eggs from hens fed varying levels of zinc. J. Food Compos. Anal. 1: 309-315.

Williams, S. N., Miles, R. D., Ouart, M. D. and Campbell, D. R. 1989. Short-term high level zinc feeding and tissue zinc concentration in mature laying hens. 